\title{
A SURVEY OF TOXICITY IN STAPHYLOCOCCI
}

\author{
BY \\ KEVIN ANDERSON \\ From the Department of Bacteriology, Guy's Hospital Medical School, London
}

(RECEIVED FOR PUBLICATION AUGUST 23, 1955)

In a recent survey of the bacteriology of hand and finger infections, the opportunity has arisen to examine the characteristics of 60 strains of Staphylococcus pyogenes. Howard (1954) has shown a positive correlation between the number of flocculation lines produced by a strain grown at right angles to an antitoxin strip and the pathogenicity of the strain for mice. $\mathrm{He}$ also found these results to show a positive correlation with the complexity of the haemolysin pattern and the titre of $\alpha$-haemolysin in broth cultures. It was decided to repeat these interesting observations and, together with additional investigations, to obtain information about staphylococci which could be regarded as primary pathogens and which came from one clinical source.

The problem of toxicity and related pathogenicity has been fully considered in a paper by Selbie (1953). It has been pointed out that since organisms from fresh sepsis largely originate from the carrier sites, any comparison of the $\alpha$-toxin titre and pigment production by strains from these two sources is unlikely to yield useful information. It seemed, therefore, that closer scrutiny of one apparently homogeneous group might reveal something of interest.

\section{Materials and Methods}

Isolation of Strains.-All the staphylococci examined were isolated from fresh septic lesions presenting in the Casualty Department for the first time. In all cases the tissue affected had previously been healthy, and only a small proportion of the patients recalled minor trauma to the part before infection. Those patients with a history of chemotherapy were excluded, as also were those who had made repeated attendances in the Casualty Department and in whom the possibility of cross-infection existed. Staphylococci were isolated on horse blood agar and later stored on nutrient agar slants at room temperature.

Pigment Production.-Strains were streaked on milk agar, incubated at $37^{\circ} \mathrm{C}$. for 18 hours, and examined after a further 18 hours at room temperature. Results were recorded as follows : +++ Bright orange pig- ment; ++ lesser degrees of orange pigment; + orange when scraped up; - no pigment when scraped up.

Fibrinolysin Production.-No satisfactory method of quantitative assay was devised. Strains were therefore grown on fibrin agar plates in the manner described by Christie and Wilson (1941) and the results recorded as either positive or negative.

Hyaluronidase Production.-This was estimated by the mucin clot prevention test described by McClean, Rogers, and Williams (1943). Hyaluronic acid was prepared from umbilical cords by precipitation with alcohol saturated with potassium acetate and the final product lyophilized in ampoules to contain approximately $80 \mathrm{mg}$. of the dried solid. Strains were grown in air for 18 hours in $5 \mathrm{ml}$. of digest broth and the cultures centrifuged at 4,000 r.p.m. for 15 minutes to free them of cells. The clear supernatant was used without filtration and the reciprocal of the highest dilution causing clot prevention was recorded as the hyaluronidase activity in units per $\mathrm{ml}$.

Alpha Haemolysin Titres in Broth Cultures.Strains were grown in nutrient broth for $\mathbf{4 8}$ hours in air containing $30 \%$ of $\mathrm{CO}_{2}$. Clear supernatants were obtained by centrifuging the cultures at 4,000 r.p.m. for 15 minutes, and doubling dilutions were made using normal saline as diluent. To each $1 \mathrm{ml}$. dilution was added $1 \mathrm{ml}$. of a $2.5 \%$ suspension in saline of rabbits' washed red cells. A control tube with 0.02 $\mathrm{ml}$. of commercial staphylococcus antitoxin (Burroughs Wellcome \& Co.) added to the lowest dilution of supernatant was set up in each experiment. Results were read after one hour's incubation in a water-bath at $37^{\circ} \mathrm{C}$. The reciprocal of the highest dilution producing $50 \%$ haemolysis was recorded as the activity in haemolytic units per $\mathrm{ml}$.

Antigen-Antibody Line Production.-Strains were grown at right angles to filter-paper strips soaked in staphylococcus antitoxin embedded in a basal medium consisting of heart infusion broth (Evan's peptone) to which $0.2 \% \mathrm{KH}_{2} \mathrm{PO}_{4}$ and $0.03 \% \mathrm{MgSO}_{4} .7 \mathrm{H}_{2} \mathrm{O}$ had been added. The $p \mathrm{H}$ was adjusted to 7.4 and agar added to a final concentration of $1.5 \%$. Amounts of $8 \mathrm{ml}$. were used, between which the antitoxin strips were embedded. Burroughs Wellcome refined staphylococcus antitoxin globulin, 15,250 units per ml., was used in all these experiments. Plates were incubated 
for 48 hours in air containing $30 \% \mathrm{CO}_{2}$, and the number of lines was counted after a further hour at room temperature.

Haemolysin Pattern.-Strains were grown at right angles to antitoxin strips embedded in the basal medium described above. The top layer contained in addition $5^{\circ}$ rabbit or sheep blood. After 48 hours incubation at $37^{\circ} \mathrm{C}$. in air contairing $30_{\circ}^{\circ} \mathrm{CO}_{2}$, the results were recorded according to the description of Elek and Levy (1950).

Mouse Pathogenicity.-The large number of strains examined precluded the use of the intramuscular method of Selbie and Simon (1952). The intraperitoneal method of Christie, North, and Parkin (1946) was therefore selected as being less time-consuming and simpler to record. Commercially bred mice (1825 g.) were used. Strains were grown on nutrient agar slants for 18 hours at $37^{\circ} \mathrm{C}$. Growth was washed off with saline and the suspensions adjusted to opacity 10 in Burroughs Wellcome tubes. One $\mathrm{ml}$. of each suspension was injected intraperitoneally into each of three mice and deaths were recorded up to 48 hours.

Coagulase Production.-In view of a recent paper by Duthie (1954) it was decided to estimate both free and bound coagulase. The methods of Duthie were closely followed, except that it was found easier to estimate bound coagulase activity by inspecting the tubes in a concave mirror rather than by transmitted light. Four grades of activity were distinguished : ++++ Massive clumping with clear supernatant fluid; +++ clumps with granular supernatant fluid: ++ scanty clumps with granular supernatant fluid : + granularity only. Four control strains showing these degrees of activity were set up with each batch of strains under test.

Free coagulase activity $(\mathrm{K})$ recorded as units per $\mathrm{ml}$. was determined using the formula $\mathrm{Kt}=100$, where $\mathrm{t}=$ time in minutes for a clot to form. The coagulable material consisted of an $0.4 \%(\mathrm{w} / \mathrm{v})$ solution of bovine fibrinogen containing also $0.5 \%(\mathrm{v} / \mathrm{v})$ rabbit plasma.

\section{Results}

In view of Howard's observations, the organisms were placed in groups according to the number of flocculation lines produced, and the other information was added in parallel columns.

Antigen-Antibody Flocculation Lines.-The maximum number of lines recorded was eight and the minimum two. There seemed no great preponderance of any one group in this series (Table I).

Fibrinolysin and Pigment Production.-There was no correlation between the production of fibrinolysin or pigment and the number of flocculation lines (Tables II and III). Consideration of all strains shows that $70 \%$ produced +++ or ++ pigment, $27 \%+$, and only $3 \%$ were achromogenic : $70 \%$ of all strains produced fibrinolysin.
Haemolysin Titre, Hyaluronidase Titre, and Mouse Pathogenicity.-The results of these investigations are summarized in Table IV. Mean values are quoted for each group, and although the trend may be appreciated by inspection, statistical analysis shows that strains producing eight, seven, and six flocculation lines all have $\alpha$ lysin titres significantly higher than the remaining

TABLE I

DISTRIBUTION OF STRAINS ACCORDING TO NUMBER OF FLOCCULATION LINES PRODUCED

\begin{tabular}{c|c}
$\begin{array}{c}\text { Number of } \\
\text { Flocculation Lines }\end{array}$ & $\begin{array}{c}\text { Number } \\
\text { of Strains }\end{array}$ \\
\hline 8 & 9 \\
7 & 8 \\
6 & 11 \\
5 & 12 \\
4 & 8 \\
3 & 6 \\
2 & 6 \\
\hline
\end{tabular}

TABLE II

RELATION OF LINE PRODUCTION TO FIBRINOLYSIN PRODUCTION

\begin{tabular}{c|c}
$\begin{array}{c}\text { Number of } \\
\text { Flocculation Lines }\end{array}$ & $\begin{array}{c}\text { Fibrinolysin: } \\
\text { Strains Positive }\end{array}$ \\
\hline 8 & 88 \\
7 & 87 \\
6 & 81 \\
5 & 50 \\
4 & 62 \\
3 & 83 \\
2 & 33 \\
\hline
\end{tabular}

TABLE III

RELATION OF I.INE PRUDUCTION TO PIGMENTATION

\begin{tabular}{|c|c|c|c|c|}
\hline \multirow{2}{*}{$\begin{array}{l}\text { Number of } \\
\text { Flocculation } \\
\text { Lines }\end{array}$} & \multicolumn{4}{|c|}{ Pigment $\%$ Strains } \\
\hline & $+\cdots$ & + & - & - \\
\hline $\begin{array}{l}8 \\
7 \\
6 \\
5 \\
4 \\
3 \\
2\end{array}$ & $\begin{array}{r}33 \\
37 \\
36 \\
9 \\
26 \\
0 \\
66\end{array}$ & $\begin{array}{l}44 \\
50 \\
36 \\
41 \\
37 \\
66 \\
17\end{array}$ & $\begin{array}{l}23 \\
23 \\
18 \\
41 \\
37 \\
34 \\
17\end{array}$ & $\begin{array}{r}0 \\
0 \\
10 \\
9 \\
0 \\
0 \\
0\end{array}$ \\
\hline
\end{tabular}

TABLE IV

DIRECT CORRELATION BETWEEN LINE PRODUCTION, MOUSE PATHOGENICITY. AND TITRES OF $\alpha$-HAEMOLYSIN AND HYALURONIDASF

\begin{tabular}{c|c|c|c}
\hline $\begin{array}{c}\text { Number of } \\
\text { Flocculation } \\
\text { Lines }\end{array}$ & $\begin{array}{c}\text { Haemolytic } \\
\text { Titre } \\
\text { (Units ml.) }\end{array}$ & $\begin{array}{c}\text { Hyaluronidase } \\
\text { Titre } \\
\text { (Units ml.) }\end{array}$ & $\begin{array}{c}\text { Mouse } \\
\text { Deaths } \\
\text { (Out of 3) }\end{array}$ \\
\hline 8 & 60 & 162 & 3 \\
7 & 52 & 107 & 25 \\
6 & 35 & 78 & 1.6 \\
5 & 8 & 49 & 1.1 \\
4 & 10 & 78 & 1.1 \\
3 & 5 & 45 & 08 \\
2 & 9 & 27 & \\
\hline
\end{tabular}


groups. Strains with eight lines have a significantly higher hyaluronidase titre than those with two, three, four, five, and six lines, and those with seven lines a higher titre than those strains with two and three flocculation lines. In these observations $\mathbf{P}=0.02$. The average number of mouse deaths is also directly related to the number of flocculation lines.

Haemolysin Pattern.-Table V shows the distribution of haemolysin patterns in this series. Single haemolysin patterns such as $\alpha$ or $\delta$ comprised only $7 \%$ of those strains with eight, seven, and six lines, whereas $25 \%$ of the remaining groups had single haemolysins.

Coagulase Activity.-Table VI summarizes the results of both types of activity. Mean values are given for each group. There is considerable uniformity of the figures, especially of bound coagulase and to a less extent with the free variety. There is no suggestion of diminishing activity in parallel with any of the characteristics so far considered.

TABLE V

DISTRIBUTION OF HAEMOLYSIN PATTERNS

\begin{tabular}{c|c|c|c|c}
\hline $\begin{array}{c}\text { Number of } \\
\text { Flocculation } \\
\text { Lines }\end{array}$ & \multicolumn{5}{|c}{ Haemolysin Pattern } \\
\cline { 2 - 5 } & $a$ & $a \delta$ & $a \beta \delta$ & $\alpha$ \\
\hline 8 & - & 9 & - & - \\
7 & 1 & 7 & - & - \\
6 & 1 & 10 & - & - \\
5 & 2 & 9 & 1 & - \\
3 & 2 & 6 & - & - \\
2 & 1 & 3 & - & \\
\hline
\end{tabular}

TARLE VI

RELATION OF LINE $\begin{aligned} & \text { PRODUCTION TO } \\ & \text { ACTIVITY }\end{aligned}$ COAGULASE

\begin{tabular}{c|c|c}
\hline $\begin{array}{c}\text { Number of } \\
\text { Flocculation } \\
\text { Lines }\end{array}$ & $\begin{array}{c}\text { Bound Coagulase } \\
\text { (Average Number of } \\
\text { Plus Signs) }\end{array}$ & $\begin{array}{c}\text { Free } \\
\text { Coagulase } \\
\text { (units ml.) }\end{array}$ \\
\hline 8 & 2.7 & 33.7 \\
7 & 3.5 & 30.7 \\
6 & 2.8 & 27.9 \\
5 & 2.5 & 39.6 \\
4 & 2.8 & 41.0 \\
3 & 30 & 54.6 \\
2 & 2.5 & 29.0 \\
\hline
\end{tabular}

Relationship of Degree of Toxin Production to Severity of Lesion.-It was noted in this analysis and also in Howard's series that a marked drop in toxigenic activity occurred between the groups containing six and five flocculation lines. It was decided to examine the clinical histories of the cases to discover if loss of activity could be correlated with the extent and severity of infection. Lesions in this series fell easily into three groups.
The first group of mild infections includes all the paronychias and subcuticular infections which either discharged spontaneously or required a minimum of surgical interference. The second group of moderately severe lesions includes all pulp space infections, either superficial or deep, which required classical surgical procedures for their relief. The final group contains such severe conditions as spreading cellulitis with lymphangitis and regional adenitis, infections of the anatomical spaces of the hand, tenosynovitis, and carbuncles. Table VII shows the results of this analysis and suggests that organisms forming large numbers of

TABLE VII

DISTRIBUTION OF CLINICAL TYPES OF INFECTION

\begin{tabular}{|c|c|c|c|}
\hline \multirow{2}{*}{ Group of Strains } & \multicolumn{3}{|c|}{$\because$ Type of Infection } \\
\hline & Severe & Moderate & Mild \\
\hline $\begin{array}{l}8,7, \text { and } 6 \text { lines (total 28) } \\
5,4,3 \text {, and } 2 \text { lines (total 32) }\end{array}$ & $\begin{array}{r}25 \\
6\end{array}$ & $\begin{array}{l}36 \\
38\end{array}$ & $\begin{array}{l}39 \\
56\end{array}$ \\
\hline
\end{tabular}

flocculation lines tend to give rise to more severe infections. A greater number of mild infections occurred with strains giving five or fewer lines. Intermediate infections appear equally distributed between the two groups. It would appear, therefore, that the degree of toxigenicity may be related to the extent of the lesion.

\section{Discussion}

It is clear that in this series the observations of Howard are confirmed. There is a direct relationship between the number of flocculation lines formed, the pathogenicity of the strain for mice, and the complexity of the haemolysin pattern. In addition the experiments of Christie et al. (1946) are confirmed since those strains most pathogenic to mice have high $\alpha$-lysin titres. To a less significant extent there is a direct relationship between line production and hyaluronidase titre. The degree to which these toxins are produced appears directly related to the severity of the clinical lesion. With regard to pigment production, coagulase activity, and fibrinolysin production the relationship, if any, is less clear. The organisms in this series, isolated from primary septic infections, comprise a group in which an abundance of orange pigment would be expected. It is probably true to say that there is no known property connected with pigmentation which may contribute to virulence and it is therefore not surprising that the variation seen in this group bears no relationship to the other toxins elaborated. No conclusions can be drawn from the testing of strains on fibrin 
agar plates. Had a satisfactory quantitative method been devised, some trend in the activity of the strains might have been detected. The percentage number of strains positive (70) is considerably lower than the figure quoted by Christie and Wilson (1941), who found that $92 \%$ of coagulasepositive human strains gave a positive result.

The investigation of coagulase activity lends considerable support to the conclusions of Hale and Smith (1945), who considered the production of coagulase to be a major factor in the initiation of an infection. All the strains in this survey are of fairly constant coagulase activity and have been successful in initiating a well-defined infection. It is reasonable to assume that the subsequent course and extent of any given lesion depends upon the ability of the strain to produce greater or lesser amounts of other toxins. Schwabacher, Cunliffe, Williams, and Harper (1945) and also Selbie agree that strains producing little or no $\alpha$-toxin are rarely responsible for primary infections. Lack and Wailling (1955), finding $18 \%$ of their strains devoid of $\alpha$-toxin, attribute this to the high proportion of strains originating from sinus and postoperative wound infections. Such organisms might be compared with those isolated from the group of "silent infections" described by Schwabacher et al., who found that $22 \%$ of these strains were lacking in $\alpha$-toxin. In the present series, only $3 \%$ of strains lacked $\alpha$-toxin and this agrees more closely with the work of Marks (1952), who found a close correlation between $\alpha$-toxin production and pathogenicity. It seems that coagulase and $\alpha$-toxin are of prime importance in the initiation and subsequent extension of an infection. It is of interest to recall a strain isolated in these laboratories from a carbuncle of the face with spreading cellulitis of the neck and chest wall together with a metastatic focus in the epididymis. This organism produced as much $\alpha$ toxin in vitro as the Wood 46 strain, and clinically it could be considered not only pathogenic but highly invasive.
It is clear that in surveys of this nature the properties of pathogenic staphylococci should be sought amongst those organisms which gain access through healthy tissue with the aid of minimal local trauma, and produce destructive lesions of greater or lesser severity. In the case of chronic sepsis and post-operative infection there is not always evidence of true tissue invasion and it is therefore not surprising that many strains from these sources are devoid of one or several toxic components. Organisms capable of colonizing damaged or necrotic tissue cannot be said to represent true pathogens.

\section{Summary}

Certain toxigenic properties of 60 strains of Staph. pyogenes are examined.

The findings of Howard are confirmed. In addition there is a direct relationship between the production of flocculation lines, hyaluronidase titre, and the severity of the lesion.

The position of coagulase and $\alpha$-toxin is reexamined. There is no evidence to suggest that these two toxins are not of prime importance in the initiation and extension of an infection.

I am indebted to Mr. Patrick Clarkson, F.R.C.S., and to the casualty officers. Guy's Hospital, for their co-operation in obtaining suitable strains for this investigation, and for access to their detailed clinical records.

\section{REFERENCES}

Christie, R., and Wilson, H. (1941). Aust. J. exp. Biol. med. Sci, 19, 329

- North, E. A., and Parkin, B. J. (1946). Ibid., 24, 73.

Duthie, E. S. (1954). J. gen. Microbiol., 10, 427.

Elek, S. D., and Levy, E. (1950). J. Path. Bact., 62, 541.

Hale, J. H., and Smith, W. (1945). Brit. J. exp. Path., 26, 209.

Howard. J. G. (1954). J. Path. Bact., 68, 177.

Lack. C. H., and Wailling, D. G. (1955). Ibid., 69, 431.

Marks, J. (1952). Ibid., 64, 175.

McClean, D., Rogers, H. J., and Williams, B. W. (1943). Lancet, 1, 355.

Schwabacher, Herta, Cwnliffe. A.C., Williams, R. E. O., and Harper, G. J. (1945). Brit. J. exp. Path., 26, 124.

Selbie, F. R. (1953). Arch. Middx Hosp., 3, 1.

__ and Simon, R. D. (1952). Brit.J. exp. Path., 33, 315 